\title{
LAB-AsSAY FOR Estimating Methane Emissions FROM DEEP-PIT SWINE MANURE STORAGES
}

\author{
D.S. Andersen ${ }^{*}$, M.B. Van Weelden, S.L. Trabue, \& L.M. Pepple
}

1. Daniel S. Andersen, Assistant Professor, Department of Agricultural and Biosystems Engineering, 3348 Elings Hall, Iowa State University, Ames, IA 50011, USA

2. Mark B. Van Weelden, Research Assistant, Department of Agricultural and Biosystems Engineering, 3348 Elings Hall, Iowa State University, Ames, IA 50011, USA

3. Steven L. Trabue, Scientists, USDA-ARS, National Laboratory for Agriculture and the Environment, 2110 University Blvd., Ames, IA 50011, USA

4. Laura M. Pepple, Livestock Extension Specialist, Agricultural \& Biological Engineering Dept., University of Illinois, 336 AESB, MC 6441304 W. Pennsylvania Avenue, Urbana, Illinois 61801, USA

* Corresponding Author: Daniel S. Andersen, 3348 Elings Hall, Iowa State University, Ames Iowa 50011; phone: 515-294-4210; e-mail: dsa@iastate.edu

\begin{abstract}
Methane emission is an important tool in the evaluation of manure management systems due to the potential impact it has on global climate change. Field procedures used for estimating methane emission rates require expensive equipment, are time consuming, and highly variable between farms. The purpose of this paper is to report a simple laboratory procedure for estimating methane emission from stored manure. The test developed was termed a methane production rate (MPR) assay as it provides a short-term biogas production measurement. The MPR assay incubation time is short (3d), requires no sample preparation in terms of inoculation or dilution of manure, is incubated at room temperature, and the manure is kept stationary. These conditions allow for high throughput of samples and were chosen to replicate the conditions within deep-pit manure storages. In brief, an unaltered aliquot of manure was incubated at room temperature for a three-days to assay the current rate of methane being generated

1

Mention of trade names or commercial products in this article is solely for the purpose of providing specific information and does not imply recommendations or endorsement by the U.S. Department of Agriculture.

USDA is an equal opportunity provider and employer.
\end{abstract}

(C) 2015. This manuscript version is made available under the Elsevier user license http://www.elsevier.com/open-access/userlicense/1.0/ 
by the manure. The results from this assay predict an average methane emission factor of $12.2 \pm 8.1 \mathrm{~kg} \mathrm{CH}_{4} \mathrm{head}^{-1}$ $\mathrm{yr}^{-1}$ per year, or about $5.5 \pm 3.7 \mathrm{~kg} \mathrm{CH}_{4}$ per finished animal, both of which compare well to literature values of $5.5 \pm$ $1.1 \mathrm{~kg} \mathrm{CH}_{4}$ per finished pig for deep-pit systems (Liu et al., 2013). The average methane flux across all sites and months was estimated to be $22 \pm 17 \mathrm{mg} \mathrm{CH}_{4} \mathrm{~m}^{-2}-\mathrm{min}^{-1}$, which is within literature values for deep-pit systems ranging from 0.24-63 $\mathrm{mg} \mathrm{CH}_{4} \mathrm{~m}^{-2}$ - $\min ^{-1}$ (Park et al., 2006) and similar to the $15 \mathrm{mg} \mathrm{CH} \mathrm{CH}^{-2}-\mathrm{min}^{-1}$ estimated by (Zahn et al., 2001).

\section{Keywords.}

Methane production rate assay, liquid manure, methane production, manure storage, manure management, methane response to temperature

\section{Introduction}

Pork production is an important component of North American agriculture. Two of the primary environmental issues facing the swine industry are manure utilization and odor mitigation. As swine production systems have become larger and more specialized, these concerns have only intensified, requiring these operations to place greater emphasis on their environmental stewardship. The most common use for swine manure is fertilizer for crop production due to its nutrient value (Hatfield et al., 1998). In most instances, this practice continues to this day; however, due to crop rotation practices where swine production is most prominent, land application windows are often limited to once or twice per year. Thus, long-term storage (6-12 months) of manure is typically required on swine farms.

In the Midwestern United States, swine finishing operations typically utilize deep-pit manure storages to hold the manure until it can be land applied. These deep-pits are located within the swine production building, beneath a slatted floor on which the pigs are raised. This allows the manure to fall through to the storage pit, where it is stored until field conditions are appropriate for land application. Storing the manure within the building limits the opportunity for rainwater dilution of the manure, minimizing manure volumes and maintaining the fertilizer value. This long-term storage of high organic matter manure coupled with anaerobic conditions, allows methanogenesis to occur. This process breaks down the organic material in the manure and produces methane.

Methane has a warming potential 25 times that of carbon dioxide and recent estimates is that methane has contributed up to $20 \%$ of the recent warming trend (Kirschke et al., 2013), making its production during manure storage a potential environmental concern. Numerous conditions impact the amount of methane produced during 
manure storage. These include: the manure temperature (Yvon-Durocher et al., 2014), atmospheric temperatures (due to the impact on barn ventilation) (Ni et al., 2008; Blanes-Vidal et al., 2008), the manure pH (Sanchez et al., 2000), potential presence of inhibitory compounds (Angelidaki and Ahring, 1993; Vedrenne et al., 2008; Petersen et al., 2012), the residence time of manure in the storage (Van Velsen, 1979; Vavilin and Angelidaki, 2005), the size and type of animal (Jungbluth et al., 2001), the diet of the animal (Lovett et al., 2003; Misselbrook et al., 1998), and the amount of residual manure remaining after land application (serves as inoculant of bacteria for fresh manure) (Zeeman, 1991; Huther et al., 1997). In general, factors leading to greater microbial development, such as increasing temperature, manure residence time, and residual manure in the storage, increase methane production from the manure. While those that reduce microbial development, the presence of inhibitory compounds or reduced manure storage times, reduce methane production.

Two methods currently exist for inventorying methane production by animal production facilities. The first method, the Intergovernmental Panel on Climate Change (IPCC) "Tier 2" approach, requires specific waste characteristics, including the maximum methane-production capacity of the manure, the mass of volatile solids excreted from the animals, and a methane conversion factor (IPCC, 1997; IPCC, 2000). The maximum methane production capacity of the manure would typically need to be determined from the use of the biochemical methane production (BMP) potential assay as described by (Owen et al., 1979; Moody et al., 2011) although the default value $\left(0.48 \mathrm{~m}^{3}\right.$ per $\mathrm{kg}$ of $\left.\mathrm{VS}\right)$ is often used for finishing swine manure. The ASABE standard ASAE D384.2 "Manure Production and Characteristics" (ASABE, 2005) is used to estimate the mass of volatile solids excreted for various livestock species. The value currently listed for finishing swine is $0.27 \mathrm{~kg} \mathrm{VS} \mathrm{day}{ }^{-1}$ animal $^{-1}$. Finally, the methane conversion factor is estimated based on IPCC suggestion for the specific manure storage type (17-25\% for long-term pit manure storage at cool temperature, 27-65\% for long-term pit manure storage at temperate temperature, and 71$80 \%$ for long-term pit manure storage at warm temperature). Using default values from the IPCC Tier 2 methodology with a MCF of $46 \%$ (average of temperature storage conditions), estimated methane emissions from a swine facility are $5.83 \mathrm{~kg} \mathrm{CH}_{4}$ per finished pig (in a grow-finish operation). Although this methodology would seem to offer a good approximation for an average facility, researchers have pointed out a substantial variation in the amount of methane being emitted (Haeussermann et al., 2006), and any practice designed to reduce methane emissions would presumably be most beneficial if its application could be targeted to operations with the largest methane emissions. 
An emission factor approach is the second methodology commonly used to estimate emissions from livestock facilities. The emission factor approach is based on using continuous measurement of air emissions for an extended period from a defined set of animal feeding operations (different species, housing systems, and manure storage). The monitored facilities were selected based on their ability to represent a substantial portion that particular animal industry. The data is then summarized and expressed as the mass of a particular substance emitted per animal (or animal unit) per unit of time, also known as an emission factor. The emission factor can then be used to estimate emissions from other animal feeding operations that have similar production facilities, management strategies, and manure management systems.

Methane emission factors determined using barn-scale methodologies provide emission estimates at high levels of accuracy (Wang et al., 2010). However, these procedures are labor intensive, require substantial investment in time and equipment, and thus are not practical for assaying large numbers of farms (Jungbluth et al., 2001). In addition, researchers measuring methane emission in the field have found significant variation in emission amounts at the animal housing level (Haeussermann et al., 2006), due in part to broad diurnal and seasonal variation (Hartung et al., 1998). Methane emission rates from swine houses ranges from 0.9 and $21.1 \mathrm{~kg}$ per animal per year (Hartung and Monteny, 2000) have been reported. This variation in emission rates among operations with similar management strategies, methane emission factors will invariably have large uncertainties when applied to specific operations. Consequently, large number of swine operations need to be surveyed for greater confidence in the reported methane emission factors, which is not practical given cost of preforming these studies.

Cheaper alternative procedures that are capable of high throughput analysis are needed. Since the majority of the methane emitted from swine deep-pit operations is thought to be associated with the stored manure (Park et al, 2006; Liu et al., 2013), focusing on the manure emissions may offer an alternative approach at estimating methane emissions from swine operations at a fraction of the cost of a whole facility monitoring program. Instead of measuring the maximum methane production capacity of the manure as in the BMP assay, measuring the actual methane production rate (MPR) directly may be a cheaper, faster alternative. Additionally, such an alternative could be used to screen operations to determine on which implementing a treatment practice would have the largest impact on methane emissions. Thus, the purpose of this study was the following: 1) develop a laboratory assay for determining methane production rates; 2) verify results of the assay against existing data; and 3) provide a brief interpretation of results in terms of its implications for manure management. 


\section{Materials and methods}

The methane production rate (MPR) assay was developed to mimic field conditions and differs from the biochemical methane production potential (BMP) in several key ways. First, the test does not inoculate the manure with anaerobic bacteria. The decision not to inoculate was based on wanting to evaluate the inherent ability of microbes already present in the manure to generate methane. Second, the test is a short-term incubation (three days) compared to the BMP incubation (45-60 days) for finality of methane production. In the case of methane emissions, ultimate potential for methane production is of less value than the rate of production. Moreover, within the storage pit, manure is continuously being added by animal excretion, this increases the amount of potential substrate for the microbes to consume. Since it was not possible or practical to continually add manure to the test system, short-term incubation was required to alleviate the possibility of substrate limitations or the manure composition being significantly altered by the microbial processing. Third, the test assay was performed at room temperature $\left(\sim 22.2^{\circ} \mathrm{C}\right)$ as opposed to the $35^{\circ} \mathrm{C}$ temperature used in a BMP since this temperature was more representative of temperature expected of deep-pit manure storages. Finally, the test vessels were not agitated during incubation to reflect conditions in a deep-pit.

\subsection{Manure Sample Collection}

Manure samples were collected on a monthly basis from 58 deep-pit swine finishing facilities located throughout Central and Southeastern Iowa (example facility shown in Fig. 1 a). Each location consisted of an in-ground manure storage, lined with concrete, and integrated into the building in which the pigs were raised. At each site, a manure pump-out port was selected and then utilized repeatedly for sample collection (example shown in Fig. $1 \mathrm{~b}$ ). The manure storages were all approximately $244 \mathrm{~cm}(8 \mathrm{ft}$.) deep; manure samples were collected from the surface of the manure with an additional sample collected for every $61 \mathrm{~cm}$ (24 inches) of manure depth, thus between one and three samples of manure were collected depending on the pit level. Samples were collected from multiple depths to evaluate if methane production was uniformly distributed throughout the manure profile and could be represented by a single sample of the manure, or if it varied with depth and multiple samples would be required to determine the manure's methane production.

The total depth of manure was determined by lowering a plastic rod to the bottom of the pit, withdrawing the rod, and measuring from the bottom of the rod to the wetted line that the manure had reached. Similarly, the amount of surface accumulation (crust/foam) on top of the manure was determined by slowly lowering a 1-L bottle down into 
the manure until the manure would just start to flow into the sampling bottle. The pole and bottle were then withdrawn from the pit and the distance from the top of the bottle to the highest point the crust/foam reached on the pole measured. The amount of surface accumulation present on the manure was subtracted from the total depth to determine the amount of manure present in the pit. Finally, manure temperature at each facility was monitored on a monthly basis. The temperature was measured from a sample collected six inches from the bottom of the pit using a digital thermometer immediately after sample collection. Manure temperatures ranged from $7^{\circ} \mathrm{C}$ in the late winter to $24^{\circ} \mathrm{C}$ in the late fall.

\subsection{Description of the Methane Production Rate Assay}

The procedure utilized at the Iowa State University Manure Management Lab is as follows. Approximately $100 \mathrm{~g}$ of homogenized liquid swine manure (mass of manure recorded) is added (i.e., poured) into a clear, $250 \mathrm{~mL}$ graduated serum bottle (Wheaton Science Products No.:223950, Millville, NJ). A sleeve stopper septa (SigmaAldrich Product No.: Z564729, St. Louis, MO) is then placed on top of the bottle to seal it from the atmosphere and bottle incubated at room temperature $\left(22.2^{\circ} \mathrm{C}\right)$ for three days. Used in this configuration the bottles head a headspace volume of approximately $170 \mathrm{~mL}$. After three days the gas tight syringe (Micro-Mate interchangeable hypodermic Syringe, Sigma-Aldrich Product No.: Z102342, St. Louis, MO) was inserted into the bottle septum, volume displacement recorded, and syringe contents injected into an infrared gas analyzer (NDIR-CH4 Gas analyzer, University Kiel, Germany) to obtain the methane content.

The methane production rate (equation 1) was calculated by adding the amount of biogas measured to the volume of the headspace in the bottle and multiplying by the methane content of the sampled gas. The headspace correction is required as all of the methane produced during the incubation isn't extracted, i.e., some remains in the head space of the bottle. The calculated value is then divided by the volume of manure used and the duration of the incubation.

$$
M P R=\frac{\% \text { Methane }\left(\text { Biogas }+V_{\text {headspace }}\right) \times \rho_{\text {manure }}}{100 M_{\text {manure }}(g) \times \text { time }}
$$

In this equation:

MPR: Methane Production Rate $\left(\mathrm{L} \mathrm{CH}_{4} \mathrm{~L}^{-1}\right.$ manure day $\left.{ }^{-1}\right)$

$\%$ Methane: The methane content of the gas sample (\%)

Biogas: The measured displacement on the gas tight syringe $(\mathrm{mL})$

$\mathrm{V}_{\text {headspace}}$ : The volume of headspace in the bottle after adding manure $(\mathrm{mL})$

$\rho_{\text {manure }}$ : the density of the manure $\left(\mathrm{g} \mathrm{mL}^{-1}\right)$ 
$\mathrm{M}_{\text {manure: }}$ : Mass of manure added to the bottle (g)

Time: Incubation time (day)

\subsection{Evaluating the Methane Production Rate Assay}

The first objective with this test was to validate that a three-day incubation length was appropriate. This was done by performing a series of six-day incubations where the methane production rate over the first three days were compared to the methane production rate over days four through six (methane production rates on days four through six were corrected to account for methane present in the headspace at the start of this period). Swine manure samples for this experiment were collected from the 58 barns surveyed in the study, with several barns represented by multiple samples as the depth of manure at the time of collection was greater than $61 \mathrm{~cm}$ (total of 61 manure samples). Methane production rates over the first three days were plotted against methane production rates over days four through six. The data was then evaluated by determining the correlation between the measured methane production rates over days one through three compared to over days four through six and evaluating if the slope of the best-fit line was significantly different from one and if the intercept was significantly different than zero. Meeting these requirements would indicate that the methane production rate from the manure remained relatively constant over this period, and indicate that these incubation hasn't caused a limitation in substrate availability or led to an increase in microbial activity or alternatively dramatically changed the microbial population such that methane production rate was altered.

\subsection{Experimental Design to Test Temperatue and Agitation Impact on Methane Production Rate}

Due to its impact on methane emissions, a method of correcting methane production that occurred at lab temperature to the amount of methane that would have been produced if the incubation was conducted at the in situ pit temperature was required. Additionally, we chose to not agitate our samples during this incubation as generally manure in storage is not agitated; however, as many incubation procedures utilize agitation (for example the BMP

procedure as detailed by Moody et al., 2011) we also chose to evaluate its impact. Thus, the objective of this experiment was to evaluate the impact agitation (shaken versus non-shaken) and temperature $\left(5,15,25\right.$, and $35^{\circ} \mathrm{C}$ ) had on the measured methane production rate of swine manure to develop a temperature correction factor and validate shaking wasn't required.

The manure for this experiment was obtained from three deep-pit swine finishing facilities in North Central Iowa. A vacuum pump was used to collect approximately $20-\mathrm{L}$ of manure at each location. The manure sample was 
collected from the midpoint of the liquid manure depth. These farms were selected from a random population and are assumed to be representative of typical swine deep-pit operations in the Midwestern United States. Total and volatile solids information on each manure sample was determined following Standard Methods for the Examination of Water and Wastewater 2540B and 2540E (APHA, 2000). Each sample was then split into 24 subsamples which received differing temperature and agitation treatments that were applied in a full factorial design with three replicates of each treatment (Fig. S1). The manure samples were incubated at 4, 15, 25, and $35^{\circ} \mathrm{C}$ for three days. At each temperature treatment, half of the samples were placed on a bench and not agitated, and the other half were placed on an orbital shaker set at $180 \mathrm{rpm}$. Biogas and methane production rates were assayed as described above.

Statistical analysis was performed in JMP Pro 10 (JMP, Version Pro 10.0.0, SAS Institute Inc., Cary, NC, 19892007) as a full factorial analysis where manure source (farm) was considered a random variable, temperature a fixed factor, mixing a fixed factor, and the interaction of temperature and mixing a fixed factor. Interactions with the random variable (manure source) were pooled into the residual error term. A means separation procedure (Fisher's protected least significant difference test) was used to evaluate the significance of temperature, mixing, and the interaction of temperature and mixing on the methane and biogas production rate. To better understand and evaluate these results the linearized Arrhenius equation was fit to the methane production rate as a function of temperature (eq. 2).

$$
k\left(L^{L C H_{4}} / L-d a y\right)=A \exp \left(\frac{-B}{T+273}\right)
$$

In this equation $k$ is the rate constant $\left(\mathrm{L} \mathrm{CH}_{4} \mathrm{~L}^{-1}\right.$ manure day $\left.{ }^{-1}\right), T$ is the temperature $\left({ }^{\circ} \mathrm{C}\right)$, and $A$ and $B$ are fitting parameters.

\subsection{Converting the Methane Production Rate to a Methane Flux}

Each manure sample (918 manure samples) were assayed for total solids, volatile solids, and the methane production rate. Of these, approximately half, 404, were also assayed for volatile fatty acid content following the procedures of Webber et al. (2010). Statistical analysis of the assayed methane production rates indicated no significant differences in the methane generation rate of samples collected from different depths $(\mathrm{p}=0.2547$, analyzed with anova blocking by farm and month and a fixed factor of depth). Thus, all samples from the same month and facility were averaged to estimate the methane production rate of the manure for that facility, i.e., samples were not limited to representing a certain layer as originally hypothesized but could be used to represent the 
continuum of the manure.

The MPR assay was performed at room temperature. The fitted Arrhenius equation developed using data collected from the temperature-agitation experiment was used to develop the temperature correction factor. The methane generation rates at the lower temperatures tested $\left(4,15\right.$, and $\left.25^{\circ} \mathrm{C}\right)$ was scaled to the percent of methane that was generated at $35^{\circ} \mathrm{C}$ for each manure as it provided a method to standardize the response of each of the samples to temperature. The temperature recorded during the manure sample collection was then used to adjust the methane production rate values measured at room temperature to the monitored in situ temperature recorded during field sample collection.

To calculate the methane flux $\left(\mathrm{L} \mathrm{CH}^{4} \mathrm{~m}^{-2}\right.$ day $\left.{ }^{-1}\right)$ the average methane production rate $\left(\mathrm{L} \mathrm{CH}_{4} \mathrm{~L} \mathrm{manure}^{-1}\right.$ day $\left.{ }^{-1}\right)$, corrected for temperature effects, was multiplied by depth of manure $(\mathrm{m})$ and appropriate conversions $\left(1000 \mathrm{~L} \mathrm{~m}^{3}\right)$ as shown in equation 3 . The methane emission was then converted to kilograms per animal space by assuming 0.9 $\mathrm{m}^{2} /$ pig space and a methane density of $0.66 \mathrm{~kg} / \mathrm{m}^{3}$.

$$
\text { Flux }=\text { MPR } \times T_{\text {correction }} \times \text { depth } \times 1000
$$

\section{Results and discussion}

Our first objective was to evaluate if a three-day incubation was an appropriate length of time for the MPR assay. This was analyzed by comparing the methane production rate over the first three days to the methane production rate over days four through six (Fig. S2). The statistical analysis of the data indicated that the methane production rates over the first three days was significantly correlated to the next three days $(\mathrm{p}<0.0001)$, that the slope of the best-fit line wasn't significantly different than one (95\% confidence interval of 0.812 to 1.06$)$ and that the intercept wasn't significantly different than zero ( $95 \%$ confidence interval of -0.028 to 0.012 ). Analysis of the residuals indicated that the distribution of residuals was approximately normal. We interpret this to mean that the methane production rate of the manure sample over a six-day incubation period is approximately constant and thus the measured value provides a characteristic of the manure based on its microbial population and the availability of carbon substrates in the sample.

Our second objective was to determine the impact that the temperature at which the incubation was conducted and whether or not the sample was agitated had on the methane production rate. Manures from three farms were used in this part of the study. Characteristics of the manures and the biogas and methane production rates they had at 
$25^{\circ} \mathrm{C}$ are provided in table 1 . These include the total solids content, the volatile solids content, the volatility of the solids (percent of solids that are volatile), the methane production rate (MPR), biogas production rate (BPR), and the methane content of the biogas (\%). Overall, the manure solids contents were typical of those found in deep-pit swine finishing facilities in Iowa.

The analysis of variance table evaluating the impact of temperature, agitation, and their interaction is for methane production rates and biogas production rates are shown as tables 2 and 3 respectively. As can be seen from the table the interaction between temperature and mixing wasn't significant for either methane $(p=0.0940)$ or biogas $(p=$ 0.3809 ) production nor was the impact of mixing ( $\mathrm{p}=0.7678$ and $\mathrm{p}=0.3304$ for methane and biogas respectively); however, the impact of temperature was very significant ( $\mathrm{p}<0.0001$ in both cases).

These results indicate that shaking should not be needed as part of the methane and biogas production assay as it did not impact the results. Moreover, not shaking the samples allowed foam to develop on top of some of the samples which could be advantageous for studying foam structure, characterizing the foam, and evaluating what is causing foam formation. The results also indicate that temperature can have a significant impact on the rate of methane and biogas production. Fisher's least significant difference test indicated that biogas and methane production rates at each temperature were significantly different $(\alpha=0.05)$ than the rate at every other temperature.

The response to temperature data were plotted in two ways. The first, shown in Fig. S3a, supplementary materials, was to fit the measured methane production rate against temperature for each of the manures. This showed that the manure from farm three had the greatest temperature response. The other two manures (farm 1 and farm 2) responded similarly to temperature. The second method was to rescale the methane production rate to percent of methane production rate at $35^{\circ} \mathrm{C}$ (Fig. S3b, supplementary materials). This rescaling resulted in all three manures exhibiting a similar temperature response pattern. In general, the data was well fit by the Arrhenius equation, indicating it is an appropriate choice for modeling the response of methane production to temperature.

A common rule of thumb is that microbial activity will approximately double with every $10^{\circ} \mathrm{C}$ increase in temperature (Westerman et al., 1989; Line et al., 1987; O’Rourke, 1968). Our data would suggest this approximation is reasonably valid as the methane production rate on average increased by 2.3 times from $4^{\circ} \mathrm{C}$ to $15^{\circ} \mathrm{C}$ and 2.8 times from $15^{\circ} \mathrm{C}$ to $25^{\circ} \mathrm{C}$, and 1.8 times from $25^{\circ} \mathrm{C}$ to $35^{\circ} \mathrm{C}$. Most importantly, this data fit illustrates that the manure temperature can greatly influence the actual rate of methane production as compared to what is projected by this assay. Thus, some form of temperature correction is required. 


\subsection{Manure Methane Production Rate}

The MPR is a measured property of the manure that accounts for both the substrate availability and the biological activity of microbes within the manure. In this work, we did not measure biological activity directly; however, several variables describing substrate availability were evaluated. These included both total solids content (volatile solids was strongly correlated to total solids) and volatile fatty acids content. Initially, the data seemed to be quite variable; however, fitting a moving average trendline (average of 20 points shown) indicated a decreasing methane production rate with increasing VFA concentration (Fig. 2a). To better evaluate this trend the samples were binned into increments similar VFA content: bin sizes were $100 \mathrm{mg} / \mathrm{L}$ between $0-1000 \mathrm{mg} / \mathrm{L}, 500 \mathrm{mg} / \mathrm{L}$ between 1000-5000 $\mathrm{mg} / \mathrm{L}, 1000 \mathrm{mg} / \mathrm{L}$ between 5000-10000 mg/L, and $2000 \mathrm{mg} / \mathrm{L}$ thereafter. A plot of MPR rate versus volatile fatty acid concentration after binning (Fig. 2b) better displayed the general trend of stable to increasing methane production rate up to a VFA concentration of near $4000 \mathrm{mg} / \mathrm{L}$ and then decreasing methane production rate with increasing volatile fatty acid concentrations thereafter. The corresponding relationship was well described by a decaying exponential curve. Similarly, Ahring et al. (1995) found that methane production rates in anaerobic digesters tended to increase until acetic acid concentrations of $6000 \mathrm{mg} / \mathrm{L}, 3700 \mathrm{mg} / \mathrm{L}$ of propionic acid concentrations, or $8800 \mathrm{mg} / \mathrm{L}$ of butyric acid occurred. This data does not necessarily indicate that higher VFA content is leading to lower methane production, only that a process imbalance between VFA creation and conversion to methane exists and that in these conditions production of methane is often slower.

A similar analysis was then performed to evaluate if the MPR was related to the total solids concentration. Similar to the VFA data, a moving average trendline (average of 20 points shown) was fit to the MPR data to evaluate if it was related to total solids (Fig. 3a and b). Based on these results samples were again binned into groups with similar total solids concentrations. In this case, bin sizes were in $0.5 \%$ increments of total solids between 1.5 and $10 \%$ total solids and then in $1 \%$ increments thereafter. Methane production rates tended to increase up to a solids concentration of around 7.2\% (average of samples collected for this work), and then slowly decline thereafter; when the solids content reached around $10 \%$ the rate of methane production rate decreased drastically. Again, this is in line with results of Fisher et al. (1984) whom found for anaerobic digesters being used to treat swine manure that methane production increased until a solids content of around 7-9\%, at which point methane production decreased rapidly with increasing solids content.

An alternative analysis of this data is to evaluate if the methane production rate is related to month, depth, or the 
manure temperature at the time of sample collection. Results of the statistical analysis indicated that all three factors were significantly $(\mathrm{p}<0.0001)$ related to the measured methane production rate. In the case of month, significantly higher methane production rates were detected in the months of November and December and to a small extent October (Fig. 4). This period corresponds to the months of, and immediately following, manure agitation and removal from the pit. A smaller, but less dramatic increase in methane production rates were also seen in June and July. This again corresponds to a time period when about $1 / 3$ of the operation conducted a manure removal event. Although not conclusive, this could indicate that mixing and suspension of the solids in the manure resulted in increased biological decomposition of organics within the manure, and as a result increased biogas production for a short time interval. The analysis also indicated that as the temperature of the manure sample at the time of manure collection increased, so did the methane production rate measured in the lab $\left(0.0131 \pm 0.0016 \mathrm{~L} \mathrm{CH}_{4} / \mathrm{L}\right.$ manure-day per $1{ }^{\circ} \mathrm{C}$ increase in temperature at collection). Conceptually this could indicate increased biologically activity within manure at the time of manure collection; however, further experimentation would be required to validate or refute this hypothesis. Finally, the depth of manure in the storage was found to be negatively correlated with the methane production rate $\left(-0.0499 \pm 0.0095 \mathrm{~L} \mathrm{CH}_{4} / \mathrm{L}\right.$ manure-day per $\mathrm{m}$ increase in manure depth). In this analysis manure depth is serving as a proxy for manure age; greater manure depths would indicate longer periods of accumulation. Slowing of gas production as manure ages would be expected as the more easily degraded organic substrates would have already been converted into methane via biological processing. That is additional substrate inputs from animal excretion represent a decreasing percent of the collected manure sample.

\subsection{Methane Emissions}

Our third objective was to evaluate if this assay could be utilized to make reasonable estimates about the amount of methane emissions a farm would produce. In our model (eq. 3), methane emissions are a function of three factors: the amount of manure in the storage, the temperature of the manure, and the methane generation rate of the manure sample as determined from the MPR assay. Based on the procedure described here, the manure is emitting $10.7 \pm 8.1$ $\mathrm{kg} \mathrm{CH}_{4}$ per pig space per year (average \pm standard deviation), or about $4.9 \pm 3.7 \mathrm{~kg} \mathrm{CH}_{4}$ per finished animal. As this procedure did not estimate enteric fermentation methane emissions from the animal we utilized the IPCC "Tier 1" approach of assuming $1.5 \mathrm{~kg} \mathrm{CH}_{4}$ year $^{-1}$ animalspace ${ }^{-1}$ to generate barn level emissions of $12.2 \pm 8.1 \mathrm{~kg} \mathrm{CH}_{4}$ per pig space per year, or about $5.5 \pm 3.7 \mathrm{~kg} \mathrm{CH}_{4}$ per finished animal. It should be noted, this estimate was based on stocking density of $0.9 \mathrm{~m}^{2}$ per pig, which includes both the space allotment in the pen as well as a portion of alleys 
pace within the barn. If actually stocking density was higher than estimated methane emissions would be smaller than estimated (same manure emission factored over more pigs), if actually stocking density was lower methane emissions would be higher than estimated.

This emission level is within the range suggested by Hartung and Monteny (2000) of 0.9 to $21.1 \mathrm{~kg}$ per animal space per year. Moreover, this result is similar to $6.4 \mathrm{~kg} \mathrm{CH}_{4}$ per finished animal measured by Pepple (2011) at one of the swine operation utilized in this study. Additionally, our average is comparable to the $5.5 \pm 1.1$ (ave. \pm s.e.m) $\mathrm{kg} \mathrm{CH}_{4}$ per finished animal for deep-pit systems found by Liu et al. (2013) in their meta-analysis of greenhouse gas emissions from swine operations. Moreover, when evaluated on a methane flux from the manure surface basis, average flux across all sites and months was estimated to be $1.3 \pm 1.0 \mathrm{~g} \mathrm{CH}_{4} / \mathrm{m}^{2}-\mathrm{hr}$, (average \pm standard deviation) which compares favorably to the $0.9 \mathrm{~g} \mathrm{CH}_{4} / \mathrm{m}^{2}$-hr estimated by Zahn et al. (2001) for under floor manure storages on swine operations. Although not conclusive, this provides strong evidence that the assay as proposed here provides a reasonable estimate of methane emissions from swine facilities with deep-pit storages.

Along with the total estimated methane emission seasonal variation of methane emissions are also of interest. To generate the seasonal pattern, the measured MPR was corrected to the measured manure temperature and multiplied by the manure depth. The geometric average and standard deviation of the methane emission estimated was averaged across all sites in each of the months. The average values tended to show seasonal trends, exhibiting lower emissions in the colder, winter months after the manure pit had recently been emptied and higher emissions in the summer months when the manure storage contained more manure (Fig. 5). The variability of the average monthly emission factor tended to show the same pattern, exhibiting substantially higher variability during the summer months. We believe this is in part due to the different manure pumping scheduled utilized at these operations; all operations were pumped in the fall (note how methane flux variability dropped in November), but only a subset of operations pumped in the spring (in May). This caused greater variation in manure depth at the operations, and as a result, a wider range of methane fluxes throughout the summer. The lower variability in August was caused by a logistical constraint that only allowed manure sample collection from 30 of the 58 sites.

The impact of manure depth, temperature, and measured methane production rate on the estimated methane flux was evaluated by plotting the estimated methane flux against each of the three variables. The measured methane production rate of the manure was most strongly correlated to the flux, describing about $50 \%$ of the variation in estimated methane flux. Temperature was the second most important variable, describing about $25 \%$ of the 
estimated methane flux, and depth was the least strongly correlated describing only $13 \%$ of the estimated methane flux (Fig. 6). The relationships between the estimated methane flux for both depth and measured methane production rate were linear, whereas the relationship between methane flux and temperature appeared to be exponential as expected from the temperature correction factor. This tends to indicate that though other factors (manure temperature, manure depth, other) play a key role in controlling methane emissions from the manure, at its heart the variability in manure methane emissions is driven by inherent differences in the manure, i.e., potentially differences in substrate availability or in development of the microbial consortia responsible for carrying out the methanogenesis sequence.

\section{Implications}

Within this section we evaluate how different management practices could impact a farm's methane emissions. The approach used is to take an example farm, estimate methane emissions from this farm, and then evaluate how a change in management practice could impact the estimated methane emissions. All calculations are performed on a per head basis.

Our base case will be a swine finishing operation that land applies manure once per year in the fall. Assume the initial manure depth is $30.5 \mathrm{~cm}$ in November, that each pig has $0.9 \mathrm{~m}^{2}$ of floor space, that the pit fills at a rate of 4.9 L/headspace-day, that the manure has a solids content of $9 \%$ as per the ASABE manure production standard, and manure remains at a constant temperature $18^{\circ} \mathrm{C}$. At this solid content, the methane production rate would be estimated at $0.0996 \mathrm{~L} \mathrm{CH}_{4} / \mathrm{L}$-day (based on Fib.e 10b) as compared to a value of $0.0921 \pm 0.0027 \mathrm{~L} \mathrm{CH}_{4} / \mathrm{L}$-day (average \pm standard error of the mean) from this data set. Using these assumptions the estimated methane emission would be $19 \mathrm{~kg} \mathrm{CH} /$ animal space-year, or about $8.7 \mathrm{~kg} \mathrm{CH}_{4} /$ finished head. Our first question is how would switching to twice a year manure application alter this estimate? Assuming everything is the same as previously stated, but adding an additional manure removal event in May, again to a depth of $30.5 \mathrm{~cm}$, would reduce the estimated methane emission to $10 \mathrm{~kg} \mathrm{CH}_{4} /$ animal space-year, or about $4.7 \mathrm{~kg} \mathrm{CH}_{4} /$ finished head; an estimated methane reduction of approximately $46 \%$.

Alternatively, the MPR assay could be used to assess methane emissions from a large number of farms and attempts could be made to, at the field level, better understand why some operations develop high rates of methane production and others do not. Studies of this type could include field evaluations on the impact of residual manure left in the storage on inoculating fresh manure, impact of microbial community structure, or the impact of other 
relevant management practices on methane emissions over a large collection of barns.

\section{Conclusions}

The emission of greenhouse gases, such as methane, has become and an important consideration in the evaluation of manure management systems. To this end, this work focused on developing a lab-assay that could be used to determine the methane production rate of manure. Components of the assay, such as incubation length, temperature, and agitation level were tested to evaluate the impact that had on the results. A model for estimating methane emissions from manures based on the amount of manure in the storage, the temperature of the manure, and a simple lab-scale manure incubation assay was described and its reasonableness as compared to other methods of estimate methane emissions assessed. The results from the MPR assay suggested that on average the methane emission factor $12.2 \pm 8.1 \mathrm{~kg} \mathrm{CH}_{4}$ per pig space per year (ave. \pm s.d), or about $5.5 \pm 3.7 \mathrm{~kg} \mathrm{CH}_{4}$ per finished animal (ave. \pm s.d) from deep-pit manure storages on swine finishing operations in Iowa. When evaluated on a methane flux basis, average flux across the 58 sites was $22 \pm 17 \mathrm{mg} \mathrm{CH}_{4} \mathrm{~m}^{-2}-\mathrm{min}^{-1}$. The large variation found in methane emissions at different farms suggests that greater analysis is needed to determine what causes differences. The presented methodology offers a potential method of characterizing a large number of manure samples for many operations, and in so doing the potential to study this component of the manure storage system and develop strategies that result in reduced methane emissions.

\subsection{Acknowledgements}

We would like to thank the Iowa Pork Producers Association and Iowa Experiment Station for providing funding to help support this research.

\section{References}

Ahring, B.K., Sandberg, M., Angelidaki, I. 1995. Volatile fatty acids as indicators of process imbalance in anaerobic digesters. Appl. Microbiol. Biot. 43, 559-565.

Akdeniz, N., Jacobson, L.D., Clanton, C.J., Hetchler, B.P. 2013. Survey on foaming deep-pit swine manure. Proceedings of the 2013 ASBE Annual International Meeting. ASABE, St. Joseph, Mich.

Angelidaki, I., Ahring, B. 1993. Thermophilic anaerobic digestion of livestock waste: The effect of ammonia. Appl. Microbiol. Biot. 38, 560-564.

APHA. 1998. Standard Methods for the Examination of Water and Wastewater. $20^{\text {th }}$ ed. American Public Health Association, Washington D.C.

ASABE Standards. 2005. D384.2 Manure production and characteristics. ASABE, St. Joseph, Mich.

Blanes-Vidal, V., Hansen, M.N., Pedersen, S., Rom, H.B. 2008. Emissions of ammonia, methane and nitrous oxide from pig houses and slurry: Effects of rooting material, animal activity and ventilation flow. Agr. Ecosyst. Environ. 124, 237-244. Doi:10.1016/j.agee.2007.10.002

Clanton, C.P., Hetchler, B.P. 2013. Survey on foaming deep-pit swine manure. Proceedings of the 2013 ASBE Annual International Meeting. ASABE, St. Joseph, Mich. 
Fischer, J.R., Iannotti, E.L., Porter, J.H. 1984. Anaerobic digestion of swine manure at various influent solids concentrations. Agr. Wastes 11, 157-166. Doi:10.1016/0141-4607(84)90042-8

Haeussermann, A., Hartung, E., Gallmann, E., Jungbluth, T. 2006. Influence of season, ventilation strategy, and slurry removal on methane emissions from pig houses. Agr. Ecosyst. Environ. 112, 115-121. Doi:10.1016/j.agee.2005.08.011

Hartung, E., Monteny, G-J. 2000. Methane (CH4) and nitrous oxide (N2O) emissions from animal husbandry. Agrartechnische Forschung 6, 62-69.

Hartung, E., Martinec, M., Brose, G., Jungbltuh, T. 1998. Diurnal course of the odor release from livestock housings and the odor reduction of biofilters. Proceedings International Conference on Odor, Water Quality, Nutrient Management and Socioeconomic Issues, Des Moines/USA, 19.-22.07.98v Volume I: Oral Presentations, 299-304.

Hatfield, J.L., Brumm, M.C., Melvin, S.W. 1998. Swine manure management. In Agricultural uses of municipal, animal, and industrial byproducts. R.J. Wright, W.D. Kemper, P.D. Millner, J.F. Power, and R.F. Korcak, ed. Conservation Res. Rep. No. 44. USDA, ARS, Washington, DC.

Husted, S. 1994. Seasonal-variation in methane emission from stored slurry and solid manures. J. Environ. Qual. 23, 585592. Doi:10.2134/jeq1994.00472425002300030026x

Huther, L., Schuchardt, F., Wilke, T. 1997. Emissions of ammonia and greenhouse gases during storage and composting of animal manures. In: Voermans, J.A.M and G.J. Monteny (Eds.), Proceedings of the International Symposium on Ammonia and Odour Control from Animal Production Facilities, Rosmalen, The Netherlands, pp. 327-334.

IPCC. 1997. Greenhouse gas inventories. Revised 1996 IPCC Guidelines for National Greenhouse Gas Inventories. International Panel on Climate Change. Cambridge University Press, Cambridge, UK.

IPCC. 2000. IPCC Good Practice guidance and uncertainty management in national greenhouse gas inventories. International Panel on Climate Change. Cambridge University Press, Cambridge, UK.

Jungsbluth, T., Hartung, E., Brose, G. 2001. Greenhouse gas emissions from animal houses and manure stores. Nutrient Cycling in Agroecosystems 60, 133 - 145. Doi:10.1023/A:1012621627268

JMP Pro 10. 2012. SAS Institute Inc., Cary, NC.

Kirschke, S., Bousquet, P., Ciasia, P., Saunois, M., Canadell, J.G., Dlugkencky, E.J., Bergamaschi, P., Bergmann, D., Blake, D.R., Bruhwiler, L., Cameron-Smith, P., Castaldi, S., Chevallier, F., Feng, L., Fraser, A., Heimann, M., Hodson, E.L., Houweling, S., Josse, B., Fraser, P.J., Krummel, P.B., Lamarque, J-F., Langenfelds, R.L., Le Quere, C., Naik, V., O’Doherty, S., Palmer, P., Pison, I., Plummer, D., Poulter, B., Rigby, M., Ringeval, B., Santini, M., Schmidt, M., Shindell, D., Simpson, I., Spahni, R., Steele, L.P., Strode, S., Sudo, K., Szopa, S., van der Werf, G., Voulgarakis, A., van Weele, M., Weiss, R., Williams, J., Zeng, G. 2013. Three decades of global methane sources and sinks. Nature Geoscience 6, 813-823. Doi:10.1038/ngeo1955

Lin, C.Y., Noike, T., Sato, K., Matsumoto, J. 1987. Temperature characteristics of the methanogenesis process in anaerobic digestion. Water Sci. Technol. 19, 299-310.

Liu, Z., Powers, W., Liu, H. 2013. Greenhouse gas emissions from swine operations: Evaluation of the Intergovernmental Panel on Climate Change approaches through meta-analysis. J. Anim. Sci. 91, 4017-4032. Doi:10.2527/jas.2012-6147

Lovett, D., Lovell, S., Stack, L., Callan, J., Finlay, M., Conolly, J., O’Mara, F.P. 2003. Effect of forage/concentrate ratio and dietary coconut oil level on methane output and performance of finishing beef heifers. Livest. Prod. Sci. 84, 135 146. Doi:10.1016/j.liprodsci.2003.09010

Masse, D.I., Croteau, F., Patni, N.K. Masse, L. 2003. Methane emissions from dairy cow and swine manure slurries stored at $10^{\circ} \mathrm{C}$ and $15^{\circ} \mathrm{C}$. Canadian. Biosystems Engineering $45,1-6$.

Misselbrook, T.H, Chadwick, D.R., Pain, B.F., Headon, D.M. 1998. Dietary manipulation as a means of decreasing N losses and methane emissions and improving herbage $\mathrm{N}$ uptake following application of pig slurry to grassland. J. Agr. Sci. 130, 183-191.

Moody, L.B., Burns, R.T., Bishop, G., Sell, S.T., \& Spajic, R. 2011. Using biochemical methane potential assays to aid in co-substrate selection for co-digestion. Appl. Eng. Agric. 7, 433-439.

Muhlbauer, R.V., Moody, L.B., Burns, R.T., Harmon, J., Stalder, K. 2010. Water consumption and conservation techniques curenlty available for swine production. Pork Checkoff Research Report. National Pork Board, Des Moines, Iowa.

Ni, J.Q., Heber, A.J., Lim, T.T., Tao, P.C. 2008. Methane and carbon dioxide emissions from two pig finishing barns. J. Environ. Qual. 37, 2001-2011. Doi:10.2134/jeq2007.0386

O'Rourke, J.T. 1968. Kinetics of anaerobic treatment at reduced temperatures. Ph.D. thesis, Stanford University, Stanford, CA. 
Park, K., Thompson, A., Marinier, M., Clark, K., Wagner-Riddle, C. 2006. Greenhouse gas emissions from stored liquid swine manure in cold climate. Atmos. Environ. 40, 618-627. doi:10.1016/j.atmosenv.2005.09.075

Pepple, L.M. 2011. Impacts of feeding dried distillers grains with solubles on aerial emissions when fed to swine. Graduate Thesis. Iowa State University. Ames, Iowa.

Petersen, S., Andersen, A., Eriksen, J. 2012. Effects of cattle slurry acidification on ammonia and methane evolution during storage. J. Environ. Qual. 41, 88-94. Doi:10.2134/jeq2011.0184

Osada, T., Rom, H., Dahl, P. 1998. Continuous measurement of nitrous oxide and methane emission in pig units by infrared photoacoustic detection. T. ASABE 41, 1109-1114.

Owen, W.F., Stuckey, D.C., Healy, J.B., Young, L.Y., McCarty, P.L. 1979. Bioassay for monitoring biochemical methane potential and anaerobic toxicity. Water Res. 13, 485-492. Doi:10.1016/0043-1354(79)90043-5

Sanchez, E., Borja, R., Weiland, P., Travieso, L., Martin, A. 2000. Effect of temperature and pH on the kinetics of methane production, organic nitrogen and phosphorus removal in the batch anaerobic digestion process of cattle manure. Bioprocess Eng. 22, 247 - 252. Doi:10.1007/s004490050727

Sharpe, R., Harper, L., Simmons, J. 2000. Methane emissions from swine houses in North Carolina. Chemosphere-Global Change Science 3, 1-6. Doi:10.1016/s1465-9972(00)00044-1

Van Velsen, A. 1979. Adaptation of methanogenic sludge to high ammonia nitrogen concentrations. Water Res. 13, 995999. Doi:10.1016/0043-1354(79)90194-5

Vavilin, V., Angelidaki. I. 2005. Anaerobic degradation of solid material: Importance of initiation centers for methanogenesis, mixing intensity, and 2D distributed model. Biotechnol. Bioeng. 89, 113-122. Doi:10.1002/bit.20323

Vedrenne, F., Beline, F., Dabert, P., Bernt, N. 2008. The effect of incubation conditions on the laboratory measurement of the methane producing capacity of livestock wastes. Bioresources Technol. 99, 146-155. Doi:10.1016/j.biortech.2006.11.043

Webber, T. E., Trabue, S.L., Ziemer, C.J., Kerr, B.J. 2010. Evaluation of elevated dietary corn fiber from corn germ meal in growing female pigs. J. Anim. Sci. 88, 192-201. Doi:10.2527/jas.2009-1896.

Westermann, P., Ahring, B.K., Mah, R. 1989. Threshold acetate concentrations for acetate catabolism by aceticlastic methanogenic bacteria. Applied. Environmental Microbiology. 55, 514.

Whitehead, T.R., Spence, C., Cotta, M.A. 2012. Inhibition of hydrogen sulfide, methane, and total gas production and sulfate-reducing bacteria in in vitro swine manure by tannins, with focus on condensed quebrach tannins. Appl. Microbiol. Biot., 1-7. Doi:10.1007/x00253-012-4562-6.

Yvon-Durocher, G., Allen, A., Bastviken, D., Condrad, R., Gudasz, C., St-Pierre, A., Thanh-Duc, N., del Giogio, P. 2014. Methane fluxes show consistent temperature dependence across microbial to ecosystem scale. Nature 507, 488-491. Doi:10.1038/nature13164

Zahn, J.A., Hatfield, J.L., Laird, D.A., Hart, T.T., Do, Y.S., DiSpirito, A.A. 2001. Functional classification of swine manure management systems based on effluent and gas emission characteristics. J. Environ. Qual.30, 635-647.

Zeeman, G. 1991. Mesophilic and psychrophilic digestion of liquid manure. Ph.D. Thesis. Wageningen Agricultural University, Wageningen.

Zhang, Q., Zhou, X.J., Cicek, N., Tenuta, M. 2007. Measurement of odour and greenhouse gas emissions in two swine farrowing operations. Canadian Biosystems Engineering 49, 613-620.

Zhao, L.Y., Manuzon, R., Brugger, M., Arnold, G., Bender, R. 2005. Air quality of swine wean-finish facilities with deeppit and pull-plug-lagoon manure storage systems. Livestock Environment VII, Proceedings of the seventh International Symposium. ASABE, St. Joseph, Mich. 
Table 1. Characteristics of the manure samples used in the study of impact of temperature and agitation on methane and biogas production rates.

\begin{tabular}{cccccccccccccc}
\hline $\begin{array}{l}\text { Manure } \\
\text { Source }\end{array}$ & \multicolumn{2}{c}{$\begin{array}{c}\text { Total Solids } \\
\text { (g/L) }\end{array}$} & \multicolumn{2}{c}{$\begin{array}{c}\text { Volatile Solids } \\
\text { (g/L) }\end{array}$} & \multicolumn{2}{c}{$\begin{array}{c}\text { Volatility } \\
\text { (\%) }\end{array}$} & \multicolumn{2}{c}{$\begin{array}{c}\text { MPR } \\
(\mathrm{L} \mathrm{CH} / \mathrm{L} \text {-day) }\end{array}$} & \multicolumn{2}{c}{$\begin{array}{c}\text { BPR } \\
\text { (L/L-day) }\end{array}$} & \multicolumn{2}{c}{$\begin{array}{c}\text { Methane } \\
\text { (\%) }\end{array}$} \\
& Ave. & St. Dev. & Ave. & St. Dev. & Ave. & St. Dev. & Ave. & St. Dev. & Ave. & St. Dev. & Ave. & St. Dev. \\
\hline Farm 1 & 57.1 & $(0.2)$ & 39.3 & $(0.4)$ & 68.8 & $(0.5)$ & 0.13 & $(0.01)$ & 0.21 & $(0.01)$ & 61.1 & $(5.1)$ \\
Farm 2 & 100 & $(2.0)$ & 79.2 & $(1.6)$ & 79.1 & $(0.4)$ & 0.12 & $(0.01)$ & 0.21 & $(0.01)$ & 60.4 & $(7.5)$ \\
Farm 3 & 83.2 & $(0.6)$ & 57.3 & $(0.6)$ & 68.9 & $(0.3)$ & 0.21 & $(0.01)$ & 0.36 & $(0.02)$ & 59.1 & $(3.9)$ \\
\hline
\end{tabular}


Table 2. Analysis of variance table for the impact of temperature and agitation on methane production rates.

\begin{tabular}{cccccc}
\hline Source & $\begin{array}{c}\text { Degrees of } \\
\text { Freedom }\end{array}$ & $\begin{array}{c}\text { Sum of } \\
\text { Squares }\end{array}$ & $\begin{array}{c}\text { Mean } \\
\text { Square Error }\end{array}$ & $\begin{array}{c}\mathbf{F} \\
\text { Ratio }\end{array}$ & Prob > F \\
\hline Manure Source & 2 & 0.06494 & 0.03247 & --- & -- \\
Temperature & 3 & 0.65984 & 0.21995 & 315.6 & $<.0001$ \\
Mixing & 1 & 0.00006 & 0.00006 & 0.088 & 0.7678 \\
Temperature x Mixing & 3 & 0.00465 & 0.00155 & 2.226 & 0.0940 \\
Error & 62 & 0.04320 & 0.00070 & & \\
\hline
\end{tabular}


Table 3. Analysis of variance table for the impact of temperature and agitation on biogas production rates.

\begin{tabular}{cccccc}
\hline Source & $\begin{array}{c}\text { Degrees of } \\
\text { Freedom }\end{array}$ & $\begin{array}{c}\text { Sum of } \\
\text { Squares }\end{array}$ & $\begin{array}{c}\text { Mean } \\
\text { Square Error }\end{array}$ & F Ratio & Prob > F \\
\hline Manure Source & 2 & 0.16499 & 0.08250 & -- & -- \\
Temperature & 3 & 0.83993 & 0.27998 & 235.5 & $<.0001$ \\
Mixing & 1 & 0.00114 & .00114 & 0.962 & 0.3304 \\
Temperature x Mixing & 3 & 0.00371 & .00124 & 1.041 & 0.3809 \\
Error & 62 & 0.07365 & .00119 & & \\
\hline
\end{tabular}




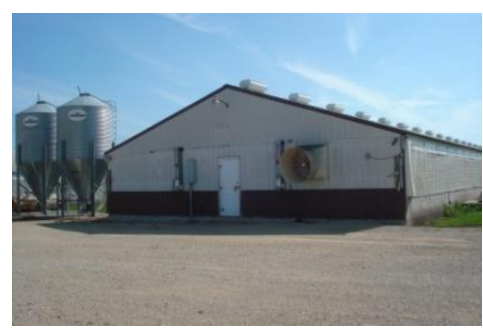

(a)

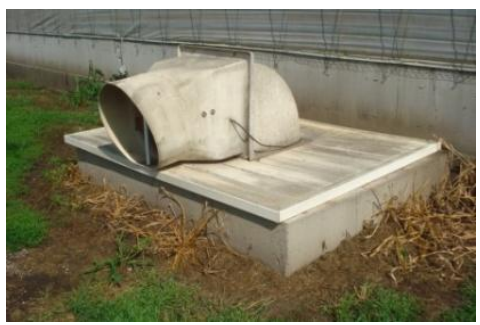

(b)

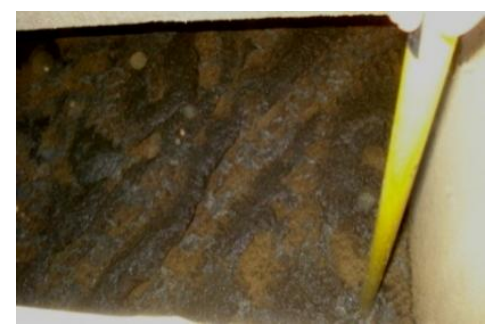

(c)

Figure 1. Examples of (a) deep-pit swine finishing facility similar to those used for manure collection for this study, (b) the pump out cover where manure samples were obtained, a sample being collected from the pump-out, and (c) a short of the plastic rod used to measure manure depth lowered into the storage. 


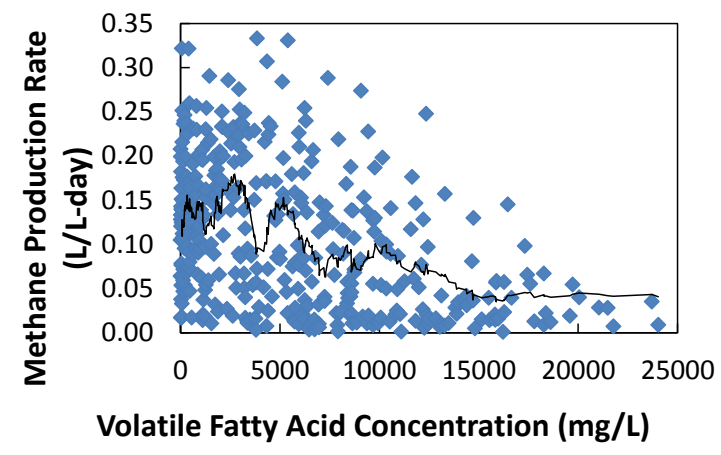

(a)

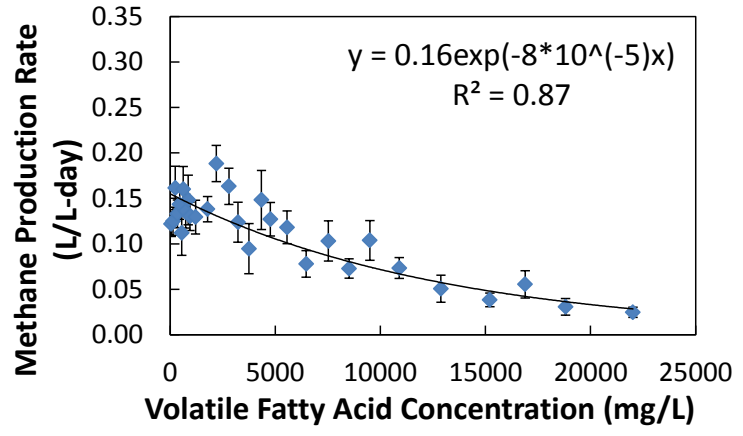

(b)

Figure 2. Relationship between volatile fatty acid concentrations and measured methane production rate among (a) all samples and (b) after binning samples with similar VFA concentrations together. Error bars represent the standard error of the mean. 


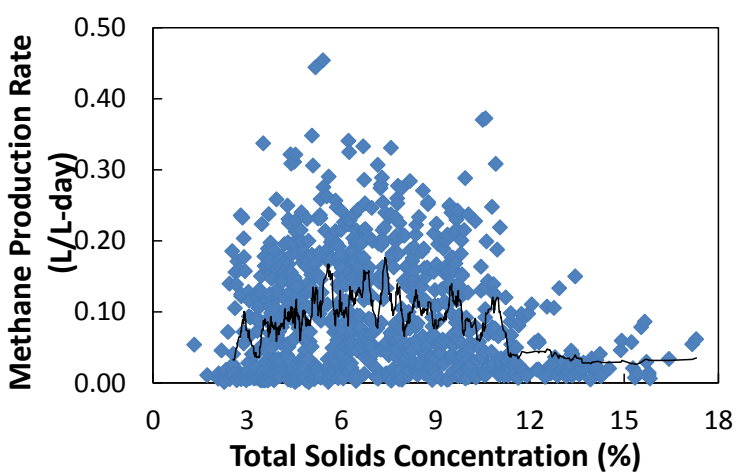

(a)

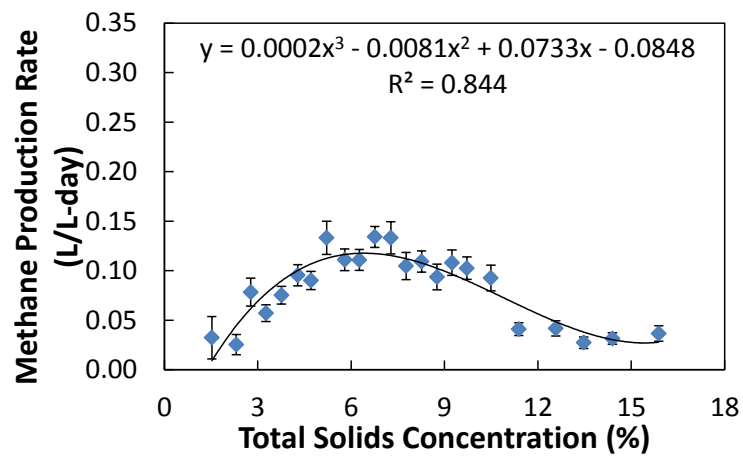

(b)

Figure 3. Relationship between total solids concentrations and measured methane production rate among (a) all samples and (b) after binning samples with similar total solids concentrations together. Error bars represent the standard error of the mean. 


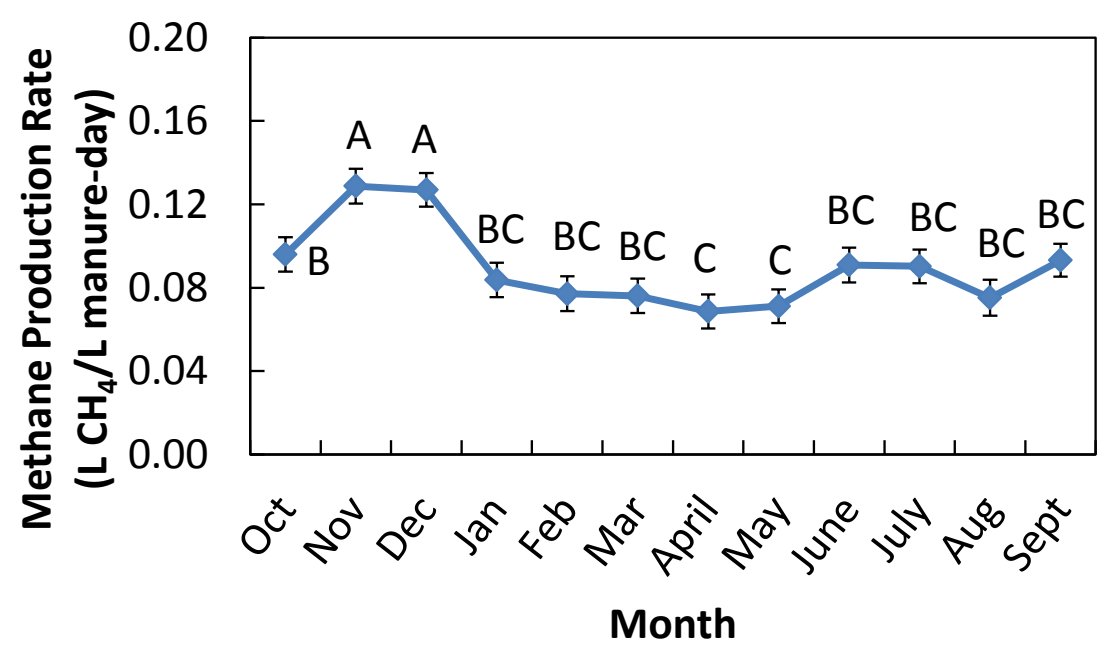

Figure 4. Average methane production rates during each month; error bars represent the standard error of the mean. Average monthly methane production rates not connected by the same letter were significantly different at $\alpha=0.05$. 


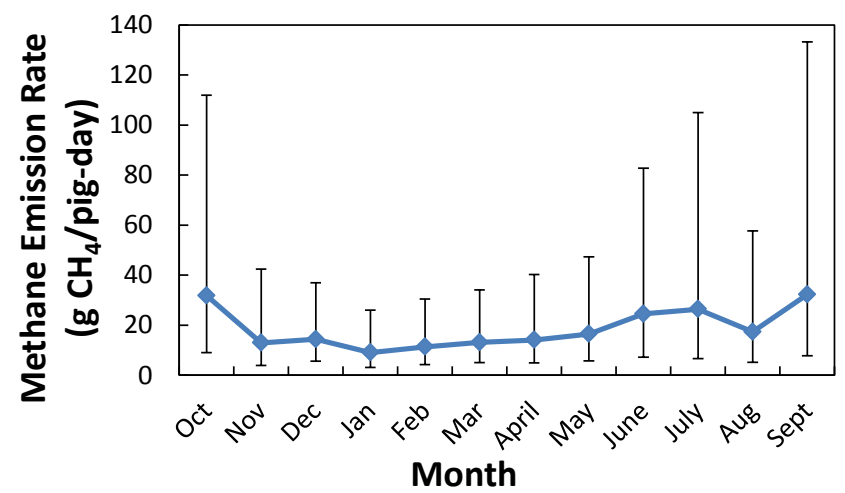

Figure 5. Seasonal variation in estimated methane flux. Error bars represent one standard deviation of the estimated fluxes. 


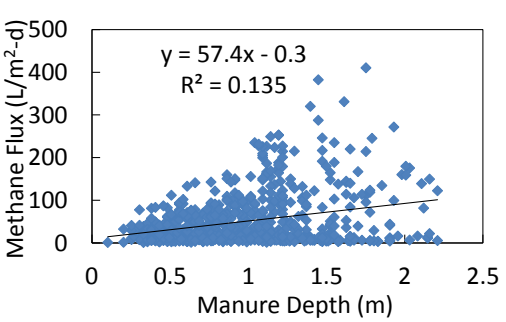

(a)

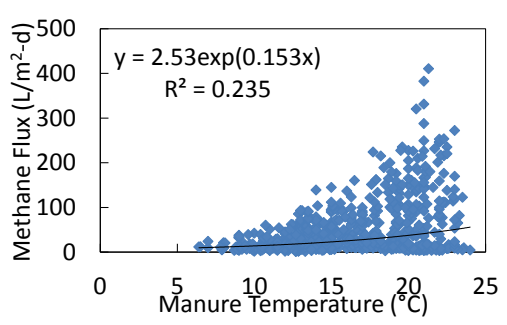

(b)

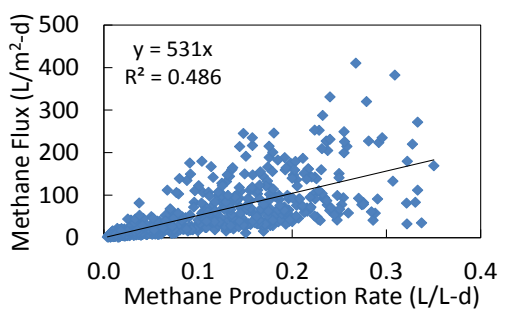

(c)

Figure 6. Correlation between the estimated methane flux and the manure depth (a), manure temperature (b), and the measured methane production rate (c). 
Figure captions

Figure 1. Examples of (a) deep-pit swine finishing facility similar to those used for manure collection for this study, (b) the pump out cover where manure samples were obtained, a sample being collected from the pump-out, and (c) a short of the plastic rod used to measure manure depth lowered into the storage.

Figure 2. Relationship between volatile fatty acid concentrations and measured methane production rate among (a) all samples and (b) after binning samples with similar VFA concentrations together. Error bars represent the standard error of the mean.

Figure 3. Relationship between total solids concentrations and measured methane production rate among (a) all samples and (b) after binning samples with similar total solids concentrations together. Error bars represent the standard error of the mean.

Figure 4. Average methane production rates during each month; error bars represent the standard error of the mean. Average monthly methane production rates not connected by the same letter were significantly different at $\alpha=0.05$.

Figure 5. Seasonal variation in estimated methane flux. Error bars represent one standard deviation of the estimated fluxes.

Figure 6. Correlation between the estimated methane flux and the manure depth (a), manure temperature (b), and the measured methane production rate (c).

Figure S1. Schematic of the experimental design of how manure was portioned among treatments from each farm.

Figure S2. Comparison of methane production rates of manure samples from 58 swine finishing operations on days 3-6 and days 1-3. The dashed line represents a one-to-one line, the solid line the best fit line. The best fit line was not statistically different than the one-to-one line.

Figure S3. Average methane production rate (a) and the average methane production rate as percent of the rate at $35^{\circ} \mathrm{C}(\mathrm{b})$ as a function of temperature with the fitted Arrhenius equation. 